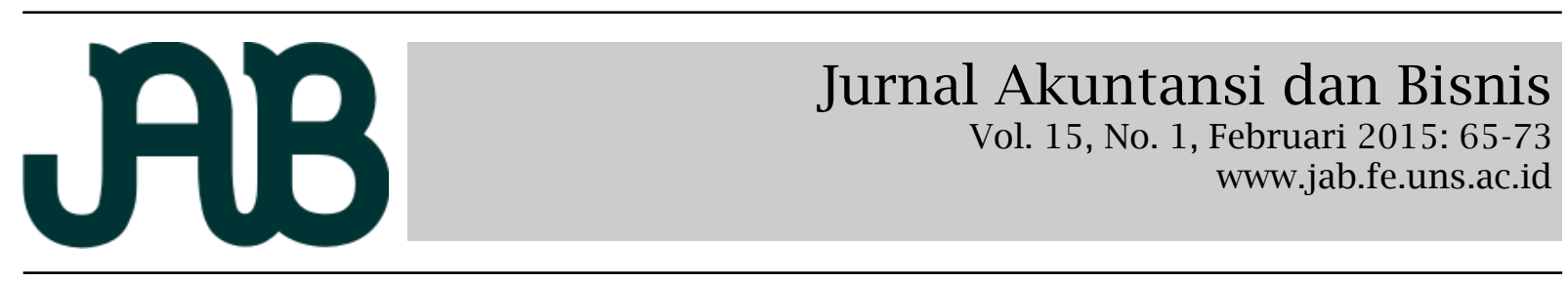

\title{
KARAKTERISTIK PEMERINTAH DAERAH KARAKTERISTIK KEPALA DAERAH, KARAKTERISTIK INSPEKTORAT DAERAH DAN KETEPATAN WAKTU PENYAMPAIAN LAPORAN KEUANGAN PEMERINTAH DAERAH INDONESIA
}

\author{
MUCHAMAD GHUFRON TAUFIK \\ BANDI (bandi.ssm@gmail.com) \\ Fakultas Ekonomi dan Bisnis Universitas Sebelas Maret
}

\begin{abstract}
A B S T R A C T
This research aims to examine the effect of local government characteristics, executive characteristics and the regional inspectorate characteristics to timeliness at the delivery of local governments financial statement (LKPD) in Indonesia. The sample used in this study were 488 local government district / cities in Indonesia for the year 2014. This study uses data of IHPS from Internal Affair Ministry of Republic of Indonesia Supreme Audit board (BPK RI), the website of Internal Affairs Ministry of Republic Indonesia, website of local government and data of regional inspectorate characteristics obtained from Financial and Development Supervisory Board (BPKP RI). This study uses a Multiple Regression Analysis model (regression analysis) to test the hypothesis.

The result showed that the local government which are age, location of local government and the role of the expert auditor level affect positively on timeliness of deliverance of local government financial statement (LKPD), while the tenure of regional head, gender oof regional head and regional inspectorate capability has no influence to timeliness in the delivernce of local government financial statement (LKPD).

Keywords: Agency theory, age, location, tenure, gender, Auditor level, capability, timeliness at the delivery of Local Government Financial Statement (LKPD).

Penelitian ini bertujuan untuk menguji pengaruh karakteristik pemerintah daerah, karakteristik eksekutif dan karakteristik inspektorat daerah untuk ketepatan waktu penyampaian Laporan Keuangan Pemerintah Daerah (LKPD) di Indonesia. Sampel yang digunakan dalam penelitian ini sebanyak 488 pemerintah dearah kabupaten/ kota di Indonesia tahun 2014. Penelitian ini menggunakan data IHPS dari Badan Pemeriksa Keuangan Pemerintah Republik Indonesis (BPK RI), website kementerian RI, website pemerintah daerah dan data karakteristik inspektorat daerah yang diperoleh dari BPK RI. Penelitian ini menggunakan model analisis regresi berganda (analisis regresi) dalam pengujian hipotesis.

Hasil penelitian menunjukkan bahwa umur pemerintah daerah, lokasi pemerintah daerah dan tingkat keahlian auditor berpengaruh postif terhadap ketepatan waktu penyampaian LKPD, sedangkan masa jabatan kepala daerah, jenis kelamin kepala daerah dan kemampuan inspektorat daerah tidak memiliki pengaruh terhadap ketepatan waktu dalam penyampaian LKPD.

Kata kunci: Teori agensi, umur, lokasi, masa jabatan, jenis kelamin, level auditor, kapabilitas, ketepatan penyampaian Laporan Keuangan Pemerintah Daerah (LKPD)
\end{abstract}

\section{PENDAHULUAN}

Akuntabilitas publik adalah prinsip yang menjamin bahwa setiap kegiatan penyelenggaraan pemerintahan dapat dipertanggungjawabkan secara terbuka oleh pelaku kepada pihak-pihak yang terkena dampak penerapan kebijakan (Krina 2003). Perwujudan transparansi dan akuntabilitas keuangan negara/daerah dalam bentuk laporan keuangan pemerintah (PP no.8 ta- hun 2006) yang secara komprehensif menggambarkan tentang kegiatan operasional, posisi keuangan, arus kas dan penjelasan atas pos-pos yang ada dalam laporan keuangan tersebut (Suhardjanto dan Lesmana 2010). Laporan keuangan yang berkualitas harus memenuhi tiga kriteria utama yaitu ketepatan waktu, keandalan dan komparabilitas (Iyoha 2012) yang juga dapat dipakai sebagai ukuran 
transparansi (Ibadin et al. 2012), walaupun tidak menjamin relevansi, tetapi relevansi informasi tidak dimungkinkan tanpa ketepatwaktuan informasi (Rachmawati 2008).

Laporan keuangan pemerintah daerah wajib disampaikan kepada BPK, 3 bulan setelah tahun anggaran berakhir (Permendagri No.13 tahun 2006), setelah terlebih dahulu dilakukan review oleh Inspektorat daerah. Menurut Johnson (1998) ketepatan waktu sangat tergantung oleh fungsi audit karena laporan keuangan tidak dapat diterbitkan sebelum audit selesai. Keterlambatan penyampaian LKPD ke BPK secara langsung memang tidak memberikan pengaruh terhadap penilaian opini, namun dapat berakibat terjadinya audit delay dan informasi dalam LKPD menjadi kehilangan kapasitasnya dalam pengambilan keputusan (Lase dan Sutaryo 2014). Fenomena keterlambatan penyampaian LKPD kepada BPK disebabkan oleh antara lain karena keterbatasan kemampuan sumber daya aparatur pemerintah dan teknologi (Indriasari dan Nahartyo 2008; Andriani 2010; Winidyaningrum dan Rahmawati 2010), umur pemerintah daerah (Setyaningrum dan Syafitri 2012; Khasanah dan Rahardjo 2014; Owusu dan Ansah 2000; Itsniawan dan Suranta 2015), masa jabatan (Singgih dan Bawono 2010; Seeba et al. 2009; Milana dan Maldaon 2015), opini, jenjang pendidikan, sertifikasi profesional auditor dan penyelenggaraan sistem informasi yang terintegrasi (Kartiko et al. 2015).

\section{TINJAUAN PUSTAKA DAN PENGEM- BANGAN HIPOTESIS Agency Theory dalam Pemerintah Daerah}

Hubungan keagenan dalam praktik pemerintah daerah dapat terwujud antara masyarakat (principal) dengan pemerintah daerah (agent), DPRD dengan pemerintah daerah dan antara masyarakat dengan DPRD (Arifianti et al. 2013). Hubungan antara keduanya melahirkan suatu kontrak dalam bentuk pemberian kewenangan (principal) dan mendapatkan kewenangan (agen) (Halim dan Abdullah 2006). LKPD yang disusun oleh kepala daerah merupakan sarana bagi masyarakat untuk melakukan monitoring dan evaluasi ter- hadap kebijakan - kebijakan yang diambil kepala daerah selaku penerima mandat dari masyarakat, sekaligus sebagai sarana untuk mengurangi konflik yang mungkin saja terjadi antara principal dengan agen sebagai akibat adanya perbedaan kepentingan antara principal dan agent (Jensen dan Meckling 1976).

\section{Laporan Keuangan Pemerintah Daerah}

Laporan keuangan merupakan laporan yang terstruktur mengenai posisi keuangan dan transaksi - transaksi yang dilakukan oleh entitas pelaporan (PP No. 71 tahun 2010). Setiap entitas organisasi pemerintahan wajib untuk membuat laporan keuangan sebagai bentuk dari pertanggungjawaban atas penggunaan keuangan negara/ daerah selama satu periode (PP No. 8 tahun 2006) sebagai syarat pendukung akuntabilitas atas aktivitas pengelolaan sumber daya publik (Ryan dan Mack 2006; Andriani 2010). Penyusunan dan penyajian LKPD harus berdasarkan pada Standar Akuntansi Pemerintah (Permendagri No.13 tahun 2006; PP No. 71 tahun 2010) dan harus memenuhi karakteristik kualitatif sebagai ukuran normatif yang perlu diwujudkan dalam informasi akuntansi pemerintah (Sari dan Witono 2014) meliputi relevan, andal dapat dibandingkan dan dapat dipahami (PP No. 71 tahun 2010). Supaya relevansi ini dapat tercapai, informasi yang dihasilkan harus memiliki manfaat umpan balik, prediktif, lengkap dan tepat waktu (Lase dan Sutaryo 2014).

\section{Ketepatan waktu Penyampaian LKPD}

Informasi dapat memberikan manfaat bagi pengambilan keputusan ketika informasi tersebut tersedia tepat pada waktunya. Tepat waktu diartikan bahwa informasi harus disampaikan sedini mungkin (Rachmawati 2008) sebelum kehilangan kemampuan untuk mempengaruhi atau membuat perbedaan dalam pengambilan keputusan (Suwardjono 2014). Ketepatan waktu dalam pelaporan keuangan merupakan karakteristik utama dalam informasi akuntansi (Owusu dan Ansah 2000), yang merupakan bagian tidak terpisahkan dari empat karakteristik kualitatif yang lain yaitu relevan, andal, dapat dibandingkan dan dapat dipahami (PP No. 71 tahun 2010). 
Karakteristik kualitatif tersebut menjadi ukuran normatif yang perlu diwujudkan dalam setiap informasi akuntansi pemerintah (Sari dan Witono 2014). Iyoha (2012) menyebutkan bahwa evaluasi terhadap kualitas laporan keuangan harus memenuhi tiga kriteria utama yaitu ketepatan waktu, keandalan dan komparabilitas (Iyoha 2012). Penyajian laporan keuangan secara tepat waktu merupakan aspek strategis untuk memperoleh keunggulan kompetitif dalam menunjang keberhasilan, kepercayaan publik, kualitas kinerja dan kredibilitas kualitas informasi akuntansi yang tinggi atas apa yang dilaporkannya (Astuti 2007), terutama pada saat kondisi keuangan dan kinerja entitas sektor publik berada di bawah pengawasan untuk mencapai efisiensi, efektivitas dan tujuan ekonomi (Cohen dan Leventis 2013).

\section{Karakteristik Pemerintah Daerah dan ketepatan waktu penyampaian LKPD}

Penelitian ini menggunakan umur administratif pemerintah daerah dan lokasi pemerintah daerah untuk menjelaskan karakteristik pemerintah daerah. Umur administrasi pemerintah daerah adalah tahun dibentuknya suatu pemerintahan daerah berdasarkan undang - undang pembentukan daerah tersebut (Lesmana 2010; Setyaningrum dan Syafitri 2012; Khasanah dan Raharjo 2014). Pemerintah daerah yang memiliki umur administratif yang lebih lama memiliki pengalaman dan kemampuan yang lebih baik dalam menyajikan laporan keuangannya secara wajar sesuai dengan SAP dibandingkan dengan pemerintah daerah otonomi baru (Setyaningrum dan Syafitri 2012), karena memiliki kredibilitas, reputasi dan kinerja yang baik (Astuti 2007) serta dapat meminimalisir faktor keterlambatan pelaporan keuangan (Owusu dan Ansah 2000). Dari uraian penjelasan tersebut, maka hipotesis penelitian $1\left(\mathrm{H}_{1}\right)$ ini dirumuskan sebagai berikut:

$\mathrm{H}_{1}$ : Umur pemerintah daerah berpengaruh positif terhadap ketepatan waktu penyampaian LKPD.

Lokasi pemerintah daerah yang dimaksud dalam penelitian ini adalah lokasi pemerintah kabupaten/kota di Jawa dan di luar Jawa. Pemisahan lokasi pemerintah daerah antara Jawa dan luar Jawa didasarkan pada kecenderungan pemerintah daerah di Jawa lebih maju baik di sektor ekonomi, infrastruktur, pendidikan dan para birokratnya memiliki tingkat intelektual yang bagus (Cohen dan Leventis 2013; Heriningsih dan Marita 2013) dengan pengorganisasian lembaga yang cukup baik (Hapsari et al. 2013), sehingga dapat mendorong ketepatan waktu penyampaian LKPD. Dengan demikian, hipotesis penelitian $2\left(\mathrm{H}_{2}\right)$ ini dapat dirumuskan sebagai berikut:

$\mathrm{H}_{2}$ : Lokasi Pemerintah Daerah Berpengaruh Positif terhadap Ketepatan Waktu Penyampaian LKPD.

Karakteristik Kepala Daerah dan ketepatan waktu penyampaian LKPDHambrick dan Mason (1984) menjelaskan bahwa seorang eksekutif memiliki karakteristik yang dapat mempengaruhi organisasi yang dipimpinnya. Pengalaman para manajer puncak, nilai - nilai dan personality mempengaruhi pilihan dan interpretasi terhadap situasi yang mereka hadapi (Hambrick dan Mason 1984). Manajer dengan pengalaman kerja yang lebih lama mempunyai hubungan yang positif dengan pengambilan keputusan sehingga berdampak pada kinerja organisasi (Kidwell et al. 1987). Pada organisasi pemerintahan, manajer dengan pengalaman kerja yang lebih lama mempunyai hubungan yang positif dengan penyelesaian pekerjaan dan pengambilan keputusan yang lebih cermat, cepat dan lebih baik sehingga berdampak pada kinerja organisasi (Singgih dan Bawono 2010; Kidwell et al. 1987; Seeba et al. 2009; Milana dan Maldaon 2015). Berdasarkan uraian di atas, maka dapat dirumuskan hipotesis penelitian 3 (H3) sebagai berikut:

$\mathrm{H}_{3}$ : Masa Jabatan Kepala daerah berpengaruh positif terhadap Ketepatan Waktu Penyampaian LKPD.

Gender merupakan keyakinan konsensus tentang perbedaan karakteristik lakilaki dan perempuan (Berry et al. 2002) yang menunjukkan perbedaan perilaku dalam bertindak didasarkan pada sifat dan kodrat yang telah diberikan secara biologis (Nugrahaningsih 2005). Secara psikologis 
kognitif dan pemasaran, wanita dikenal lebih efisien dan efektif dalam memroses Semakin tinggi level APIP maka semakin tinggi kapabilitasnya (Perka BPKP No.PER 1633/K/JF/2011). Semakin tinggi capaian level penilaian pengendalian internal maka semakin baik kinerja keuangannya (Aikins 2011) dan memberikan pengaruh terhadap ketepatan waktu pelaporan keuangan (Astuti 2007; Schmidt dan Wilkins 2013). Berdasarkan uraian tersebut, maka dapat dirumuskan hipotesis penelitian $6\left(\mathrm{H}_{6}\right)$ sebagai berikut:

$\mathrm{H}_{6}$ : Kapabilitas Inspektorat daerah berpengaruh positif terhadap ketepatan waktu penyampaian LKPD.

\section{METODE PENELITIAN \\ Populasi dan Sampel}

Populasi dalam penelitian ini meliputi seluruh pemerintah daerah di Indonesia tahun 2014. Sampel penelitian ini berjumlah 488 yang diperoleh dengan menggunakan metode purposive sampling dengan kriteria yaitu: 1) pemerintah kabupaten/ kota di Indonesia tahun 2014 yang tercatat pada Kemendagri dan BPK RI; 2) pemerintah daerah kabupaten/kota di indonesia yang wajib menyampaikan LKPD tahun 2013; 3) pemerintah kabupaten/kota yang tidak wajib menyampaikan LKPD tahun 2013.

\section{Jenis dan Sumber Data}

Penelitian menggunakan data sekunder yang diperoleh dari IHPS BPKRI tahun
2014, BPKP, buku profil kepala daerah dan mengakses website www.kemendagri.go.id, www.bpk.go.id serta website masing - masing pemerintah daerah.

\section{Definisi Operasional dan Pengukuran Variabel}

Variabel dependen yang digunakan dalam penelitian ini adalah ketepatan waktu penyampaian LKPD (TIMELINESS) yang dikategorikan ke dalam 5 kelompok yaitu kode 1 (sangat tidak tepat waktu), 2 (tidak tepat waktu), 3 (kurang tepat waktu), 4 (tepat waktu) dan 5 (sangat tepat waktu). Variabel independen dalam penelitian ini adalah karakteristik pemerintah daerah (umur administratif pemerintah daerah dan lokasi pemerintah daerah), karakteristik kepala daerah (masa jabatan kepala daerah dan gender kepala daerah) dan karakteristik inspektorat daerah (jenjang JFA dan kapabilitas inspektorat daerah).

\section{Metode Analisis Data}

Penelitian ini menggunakan alat statistik regresi dalam pengujian hipotesisnya. $\mathrm{Ru}-$ mus Persamaan regresi yang digunakan adalah sebagai berikut:

TIMELINESS: $\alpha+\beta_{1} U A_{-} P E M+\beta_{2} L K S+$ $\beta_{3}$ TENURE + $\beta_{4}$ GENDER_KD+ $\beta_{5} A H-$ $L I+\beta_{6} C A P A B I L I T Y+e$

Keterangan: TIMELINESS: ketepatan waktu penyampaian LKPD, UA_PEM: Umur Administratif Pemerintah Daerah, LKS: Lokasi Pemerintah Daerah,

Tabel 1

Definisi Operasional dan Pengukuran Variabel

\begin{tabular}{|c|c|c|}
\hline Nama & Akronim & Pengukuran \\
\hline Variabel Dependen & & Skala ordinal (1) sangat tepat waktu, (2) tepat waktu, (3) \\
\hline $\begin{array}{l}\text { Ketepatan waktu pen- } \\
\text { yampaian LKPD }\end{array}$ & TIMELINESS & $\begin{array}{l}\text { kurang tepat waktu, (4) tidak tepat waktu dan (5) sangat } \\
\text { tepat waktu }\end{array}$ \\
\hline Variabel Independen & & \\
\hline $\begin{array}{l}\text { Umur administratif } \\
\text { Pemerintah daerah }\end{array}$ & UA_PEM & $\begin{array}{l}\text { Berdasarkan jumlah waktu Tahun sejak berdirinya Pem- } \\
\text { da berdasarkan UU }\end{array}$ \\
\hline $\begin{array}{l}\text { Lokasi Pemerintah Dae- } \\
\text { rah }\end{array}$ & LKS & $\begin{array}{l}\text { Variable dummy yang diukur dengan angka (1) untuk } \\
\text { pemda di Pulau Jawa dan (0) untuk pemda di luar jawa }\end{array}$ \\
\hline $\begin{array}{l}\text { Masa jabatan Kepala } \\
\text { Daerah }\end{array}$ & TENURE & $\begin{array}{l}\text { Berdasarkan jumlah waktu selama kepala daerah men- } \\
\text { jabat sejak dilantik sampai dengan periode penelitian } \\
\text { dihitung berdasarkan Tahun }\end{array}$ \\
\hline Gender Kepala Daerah & GENDER_KD & $\begin{array}{l}\text { Variable dummy yang diukur dengan angka (0) untuk } \\
\text { kepala daerah perempuan dan (1) untuk kepala daerah } \\
\text { laki-laki }\end{array}$ \\
\hline $\begin{array}{l}\text { Jenjang Jabatan } \\
\text { Fungsional Auditor }\end{array}$ & AHLI & Jumlah JFA AHLI dibagi total JFA \\
\hline Kapabilitas Inspektorat & 3ILITY & Skor berdasarkan model IA-CM, \\
\hline
\end{tabular}

Sumber: UU No. 1/ 2004, PP No. 8/ 2006; Permendagri No. 21 tahun 2011; Ibadin et al. 2012; Suhardjanto dan Yulianingtyas 2011; Perka BPKP PER-1633/J/JF/2011 
Kepala Daerah, GENDER: Gender Kepala

Daerah, AHLI: Jenjang JFA, CAPABILITY: Kapabilitas Inspektorat Daerah, $\alpha$ : konstan-

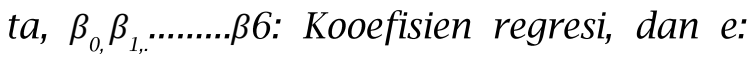
Standar error.

\section{ANALISIS DAN PEMBAHASAN}

Variabel ketepatan waktu penyampaian LKPD mampu dijelaskan oleh variabel independen berupa UA_PEM, LKS, GENDER, TENURE, AHLI dan CAPABILITY sebesar $33,7 \%$ dan sisanya sebesar $66,3 \%$ dipengaruhi oleh variabel lain yang tidak diikutsertakan dalam model penelitian ini. Nilai $p$-value sebesar $0,000<0,05$, maka secara simultan variabel UA_PEM, LKS, GENDER, TENURE, AHLI dan CAPABILITY berpengaruh pada ketepatan waktu penyampaian LKPD.

Hasil pengujian membuktikan bahwa umur administrasi pemerintah daerah berpengaruh signifikan terhadap ketepatan waktu penyampaian LKPD pada tahun 2014. Semakin tua umur pemerintah daerah maka semakin banyak pengalaman yang dimiliki sehingga mendorong pemerintah daerah dalam dalam menjalankan sistem pengelolaan keuangan dan semakin menyadari mengenai pentingnya ketepatan waktu pelaporan keuangan, temuan ini mengkonfirmasi hasil penelitian Ifada (2009) dan Owusu dan Ansah (2000). Hasil penelitian ini sejalan dengan penelitian yang dilakukan oleh Itsniawan dan Suranta (2015) dan Hartanto (2015) yang menyebutkan bahwa faktor pengalaman (umur) pemerintah daerah berpengaruh signifikan terhadap ketepatan waktu penyampaian laporan keuangan pemerintah daerah. Namun penelitian ini bertolak belakang dengan penelitian yang dilakukan oleh Saleh (2004), Astuti (2007), Ifada (2009), Septriana (2010) dan Murniati (2012)

Lokasi pemerintah daerah berpengaruh terhadap ketepatan waktu penyampaian LKPD. Hal ini membuktikan bahwa ketepatan waktu penyampaian LKPD dipengaruhi oleh letak/lokasi dari pemerintah daerah tersebut. Hasil ini, mendukung dari teori yang telah dijelaskan dalam pengembangan hipotesis sebelumnya, bahwa dengan sumber daya dan infra- struktur yang dimiliki oleh pemerintah daerah di pulau jawa dapat memberikan andil yang cukup besar terhadap ketepatan waktu penyampaian LKPD. Penelitian ini selaras dengan penelitian yang dilakukan oleh Liu et al. (1999), Cohen dan Laventis (2013) dan Mahardini (2014) yang menyatakan bahwa faktor lokasi geografis memberikan pengaruh terhadap kinerja pemerintah daerah, namun hasil penelitian ini tidak sesuai dengan penelitian yang dilakukan oleh Indriasari dan Nahartyo (2008); Suhardjanto dan Yulianingtyas (2011).

Gender tidak terbukti mempengaruhi ketepatan waktu penyampaian LKPD. Hasil penelitian ini mendukung penelitian yang dilakukan oleh Kidwell et al. (1987), Nugrahaningsih (2005), Milana dan Maldaon (2015), Nugraha dan Januarti (2015) bahwa perempuan dan laki-laki memiliki penilaian serta keputusan yang sama ketika menghadapi pertimbangan yang membutuhkan ketepatan. Hasil penelitian ini menegaskan bahwa kepemimpinan laki laki dan perempuan sebenarnya memiliki kemampuan yang sama menjadi seorang pemimpin yang efektif. Perbedaan gender tidaklah menjadi masalah, karena yang paling penting adalah memiliki efektifitas dan kredibilitas dalam memimpin sehingga dapat mencapai tujuan organisasi (Sasmita dan Raihan 2014).

Demikian pula masa jabatan kepala daerah tidak berpengaruh terhadap ketepatan waktu penyampaian LKPD. Hasil ini membuktikan bahwa tidak ada perbedaan antara kepala daerah dengan masa jabatan yang lebih lama dan kepala daerah dengan masa jabatan yang lebih pendek terhadap ketepatan waktu penyampaian LKPD. Alasan yang dapat diungkapkan adalah kerena proses penyusunan dan pelaporan keuangan daerah tidak dilakukan secara langsung oleh kepala daerah, namun dilakukan oleh perangkat daerah masing - masing (Permendagri No. 13 tahun 2006). Hasil penelitian ini tidak konsisten dengan penelitian yang dilakukan oleh Kidwell et al. (1987), Finkelstein dan Hambrick (1990), Seeba et al. (2009), Prasetyo (2014) dan Milana dan Maldaon (2015) yang membuktikan bahwa manajer 
dengan pengalaman kerja yang lebih lama mempunyai hubungan positif dengan pengambilan keputusan etis sehingga berpengaruh terhadap kinerja organisasi.

Jenjang JFA terbukti mempengaruhi ketepatan waktu penyampaian LKPD. Hal ini tentu saja memberikan bukti bahwa auditor dengan tingkat keahlian yang tinggi maka audit judgment yang diambil akan semakin baik dan tepat (Praditaningrum dan Januarti 2012) serta hasil pemeriksaan yang dilakukannya semakin berkualitas (Sukriah et al. 2009). Jika kemampuan yang dimilikinya baik dan dapat mencapai target yang ditetapkan maka batasan waktu yang telah ditentukan dapat terpenuhi sehingga pelaporan keuangan dari SKPD tersebut dapat menjadi tepat waktu (Lismawati 2012). Semakin banyak jumlah jabatan fungsional auditor ahli pada Inspektorat Kabupaten/kota, maka berdampak terhadap penyampaian laporan keuangan pemerintah daerah menjadi lebih tepat waktu (Lase dan Sutaryo 2014). Hasil penelitian ini konsisten dengan penelitian yang dilakukan oleh Indriasari dan $\mathrm{Na}$ hartyo (2008); Singgih dan Bawono (2010); Lismawati (2012); Lase dan Sutaryo (2014); Sari dan Witono (2014); Kusumaningrum dan Sutaryo (2015) dan Kartiko et al. (2015) yang menyebutkan bahwa kecakapan profesional dan kualitas auditor merupakan karakteristik penting dalam mendukung ketepatwaktuan pelaporan keuangan.

Pengujian terhadap kapabilitas inspektorat daerah terbukti tidak berpengaruh pada ketepatan waktu penyampaian LKPD. Hasil ini konsisten dengan penelitian Toding dan Wirakusuma (2013); Kusumaningrum dan Sutaryo (2015) yang mengungkapkan bahwa kapabilitas dan reputasi Auditor internal tidak berpengaruh secara signifikan terhadap ketepatan waktu pelaporan keuangan. Namun di sisi lain penelitian ini tidak konsisten dengan Schmidt dan Wilkins (2013) yang menyebutkan bahwa reputasi auditor mempunyai pengaruh terhadap ketepatan waktu pelaporan. Capaian level kapabilitas inspektorat daerah di Indonesia pada tahun 2014 yang masing rendah dengan rata - rata berada pada level 1 (initial) pada model IACM, menjadi alasan penyebab yang cukup kuat bahwa kapabilitas inspektorat tidak memberikan pengaruh positif terhadap ketepatan waktu penyampaian LKPD .

\section{SIMPULAN}

Penelitian ini bertujuan untuk menguji pengaruh dari karakteristik pemerintah daerah, karakteristik kepala daerah dan karakteristik inspektorat daerah terhadap ketepatan waktu penyampaian LKPD. Berdasarkan hasil analisis dan pengujian hipotesis yang telah dilakukan maka dapat ditarik kesimpulan bahwa umur pemerintah daerah, lokasi pemerintah daerah dan jenjang Jabatan Fungsional Auditor (Ahli) memberikan pengaruh terhadap ketepatan waktu penyampaian LKPD. Namun disisi lain penelitian ini menemukan bahwa gender kepala daerah, masa jabatan kepala daerah dan kapabilitas inspektorat daerah tidak berpengaruh terhadap ketepatan waktu penyampaian LKPD. Penelitian ini memiliki keterbatasan yaitu level kapabilitas inspektorat pada tahun 2014 yang cenderung didominasi pada level 1, menyebabkan terjadinya pengelompokkan pada kode 1, sehingga hal ini memberikan pengaruh terhadap hasil penelitian. Penelitian selanjutnya dapat menggunakan data hasil assessment internal control - IACM yang terbaru dengan level kapabilitas yang lebih beragam sehingga dapat diperoleh hasil yang lebih konsisten.

\section{DAFTAR PUSTAKA}

Aikins, S.K. 2011. An Examination of Government Internal Audits' Role in Improving Financial Performance. Journal of Public Finance and Management, 11 (4): 306-337.

Andriani, W. 2010. Pengaruh Kapasitas Sumber Daya Manusia dan Pemanfaatan Teknologi Informasi terhadap Keterandalan dan Ketepatwaktuan Laporan Keuangan Pemerintah Daerah (Studi pada Pemerintah Daerah Kab. Pesisir Selatan). Jurnal Akuntansi dan Manajemen, 5 (1): 69-80.

Arifianti, H., Payamta dan Sutaryo. 2013. Pengaruh Pemeriksaan dan 
Pengawasan Keuangan Daerah terhadap Kinerja Penyelenggaraan Pemerintahan Daerah (Studi Empiris pada Pemerintah Kabupaten/Kota di Indonesia). Simposium Nasional Akuntansi XVI, Manado, Indonesia.

Astuti, C.D. 2007. Faktor - Faktor yang Berpengaruh terhadap Ketepatan Waktu Pelaporan. Jurnal Informasi, Perpajakan, Akuntansi dan Keuangan Public, 2 (1): 27-42.

Berry, J.W., Y.H. Poortings, M.H. Segall dan P.R. Dasen. 2002. Cross-Cultural Psychology Research and Application. 2ed. Cambridge University Press.

Cohen, S. dan S. Leventis. 2013. Effects of Municipal, Auditing and Political Factors on Audit Delay. Accounting Forum, 37 (1): 40-53.

Gusti, M. dan S. Ali. 2008. Hubungan Skeptisisme Profesional Auditor dan Situasi Audit, Etika, Pengalaman serta Keahlian Audit dengan Ketepatan Pemberian Opini Auditor oleh Akuntan Publik. Simposium Nasional Akuntansi XI, Pontianak, Indonesia.

Finkelstein, S. dan D.C. Hambrick. 1990. Top-Management-Team Tenure and Organizational Outcomes: The Moderating Role of Managerial Discretion. Administrative Science Quarterly, 35: 484-503.

Halim, A. dan S. Abdullah. 2006. Studi atas Belanja Modal pada Anggaran Pemerintah Daerah dalam Hubungannya dengan Belanja Pemeliharaan dan Sumber Pendapatan. Jurnal Akuntansi Pemerintah, 2 (2). 2010. Hubungan dan Masalah Keagenan di Pemerintah Daerah: Sebuah Peluang Penelitian Anggaran dan Akuntansi. Jurnal Akuntansi Pemerintah, 2 (1): 53 - 64.

Hambrick, D.C. dan P.A. Mason. 1984. Upper Echelons: The Organization as a Reflection of Its Top Managers. The Academy of Management Review, 9 (2): 193-206.

Hapsari, S.I., Sutaryo dan I.F. Wijaya. 2013. Penentu Jumlah Temuan BPK atas Sistem Pengendalian Intern dan
Kepatuhan (Internal Control Compliance Comments) Pemerintah Daerah di Indonesia. Simposium Nasional Akuntansi XVI, Manado, Indonesia.

Hartanto, R. 2015. Analisis Penyelesaian Tindak Lanjut Hasil Pemeriksaan BPK RI (Perspektif Karakteristik Auditee, Karakteristik Auditor BPK, Katerakteristik Eksekutif dan Karakteristik Legislatif Daerah). Tesis, Universitas Sebelas Maret, Surakarta.

Heriningsih, S. dan Marita. 2013. Pengaruh Opini Audit dan Kinerja Keuangan Pemerintah Daerah terhadap Tingkat Korupsi Pemerintah Daerah (Studi Empiris pada Pemerintah Kabupaten dan Kota di Pulau Jawa). Buletin Ekonomi, 11 (1): 1-86.

Ibadin, I.M., F. Izedonmi dan P.O. Ibadin. 2012. The Association between Selected Corporate Governance Attributes, Company Attributes and Timeliness of Financial Reporting in Nigeria. Research Journal of Finance and Accounting, 3 (9).

Ifada, L.M. 2009. Faktor-Faktor yang mempengaruhi Ketepatan Waktu Pelaporan Keuangan (Studi Kasus Perusahaan Manufaktur di BEJ). JAI, 5 (1): 43-56.

Indriasari, D. dan E. Nahartyo. 2008. Pengaruh Kapasitas Sumberdaya Manusia, Pemanfaatan Teknologi Informasi, dan Pengendalian Intern Akuntansi terhadap Nilai Informasi Pelaporan Keuangan Pemerintah Daerah (Studi pada Pemerintah Kota Palembang dan Kabupaten Ogan Ilir). Simposium Nasional Akuntansi XI, Pontianak, Indonesia.

Itsniawan, A.M. dan S. Suranta. 2015. Audit Report Lag pada Pemerintah Kabupaten/Kota di Indonesia. Seminar Nasional Ekonomi Manajemen dan Akuntansi (SNEMA), Fakultas Ekonomi Universitas Negeri Padang, Indonesia.

Iyoha, F.O. 2012. Company Attributes and The Timeliness of Financial Reporting In Negeria. Business Intelligence Journal, 5 (1): 41-49. 
Jamilah, S., Z. Fanani dan G. Chandrarin. 2007. Pengaruh Gender, Tekanan Ketaatan, dan kompleksitas Tugas terhadap Audit Judgment. Simposium Nasional Akuntansi X, Makassar, Indonesia.

Jensen, M. dan W. Meckling. 1976. Theory of the Firm: Managerial Behavior, Agency Cost and Ownership Structure. Journal of Financial Economics, 3 (4): 305-360.

Johnson, L.E. 1998. Further Evidence on The Determinants of Local Government Audit Delay. Journal of Public Budgeting, Accounting and Financial Management, 10 (3): 375-397.

Kartiko, S.W., Fitriany, S.V.N.P. Siregar. 2015. Pengaruh Opini Audit, Kualitas Audito dan Sistem Informasi Akuntansi terhadap Keterlambatan Penerbitan Laporan Hasil Pemeriksaan Laporan Keuangan Pemerintah Daerah. Simposium Nasional Akuntansi 18, Medan, Indonesia.

Khasanah, N.L. dan S.N. Rahardjo. 2014. Pengaruh Karakteristik, Kompleksitas, dan Temuan Audit terhadap Tingkat Pengungkapan Laporan Keuangan Pemerintah Daerah, Diponegoro Journal of Accounting, 3 (3): 1-11.

Kidwell, J.M., R.M. Stevens dan A.L. Bethke. 1987. Differences in Ethical Perceptions between Male and Female Managers: Myth or Reality?, Journal of Business Ethics, (6): 489-493.

Krina, L.L.P. 2003. Indikator dan Alat Ukur Prinsip Akuntabilitas, Transparansi dan Partisipasi. Sekretariat Good Public Governance Badan Perencanaan Pembangunan Nasional, Jakarta.

Kusumaningrum, N.A. dan Sutaryo. 2015. Pengaruh Karakteristik Inspektorat Daerah dan Kinerja Penyelenggaraan Pemerintah Daerah. Simposium Nasional Akuntansi 18, Medan, Indonesia.

Lase, Y. dan Sutaryo. 2014. Pengaruh Karakteristik Auditor terhadap Audit Delay Laporan Keuangan Pemerintah Daerah. Simposium Nasional Akuntansi XVII, Mataram, In- donesia.

Lesmana, S.I. 2010. Pengaruh Karakteristik Pemerintah Daerah terhadap Tingkat Pengungkapan Wajib di Indonesia. Tesis, Universitas Sebelas Maret, Surakarta.

Lismawati. 2012. Pengaruh Kemampuan Sumber Daya Manusia terhadap Keterandalan dan Ketepatwaktuan Pelaporan Keuangan Pemerintah Daerah. Jurnal Ekonomi dan Perencanaan Pembangunan (JEPP), 4 (4).

Liu, A.y., S. Li dan Y. Gao. 1999. Location. The China Business Review, 26 (2): 20-25.

Mahardini, N.Y. 2014. Pengaruh Karakteristik Kepala Daerah terhadap Kinerja Keuangan Pemerintah Daerah di Methods and Organizational Studies, 418-425.

Sasmita, J. dan S.A. Raihan. 2014. Kepemimpinan Pria dan Wanita. Proceeding Of The 6th NCFB And Doctoral Colloquium Towards A New Indonesia Business Architecture. Fakultas Bisnis dan Pascasarjana Unika Widya Mandala, Surabaya, Indonesia.

Schmidt, J. Dan M.S. Wilkins. 2013. Bringing Darkness to Light: The Influence of Auditor Quality and Audit Committee Expertise on the Timeliness of Financial Statement Restatement Disclosures. A Journal of Practice and Theory American Accounting Association, 32 (1): 221244.

Seeba, A.A., J. Wallace dan N. Cornelius. 2009. Managerial Characteristics, Strategy and Performance in Local Government. Measuring Business Excellence, 13 (4): 12-21.

Septriana, I. 2010. Analisis Faktor - Faktor yang Berpengaruh terhadap Ketepatan Waktu Pelaporan Keuangan Perusahaan BUMN di Indonesia. Jurnal Maksi, 10 (1): 97-117.

Setyaningrum, D. dan F. Syafitri. 2012. Analisis Pengaruh Karakteristik Pemerintah Daerah terhadap Tingkat Pengungkapan Laporan Keuangan, Jurnal Akuntansi dan Keu- 
angan Indonesia, 9 (2): 154-170.

Singgih, E.M dan I.R. Bawono. 2010. Pengaruh Independensi, Pengalaman, Due Professional Care dan Akuntabilitas terhadap Kualitas Audit (Studi pada Auditor di KAP "Big Four" di Indonesia). Simposium Nasional Akuntansi XIII, Purwokerto, Indonesia.

Suhardjanto, D. dan S.I. Lesmana. 2010. Pengaruh Karakteristik Pemerintah Daerah terhadap Tingkat Pengungkapan Wajib di Indonesia. Jurnal STIE Bank BPD Jateng, 6 (2). dan R.R. Yulianingtyas. 2011. Pengaruh Karakteristik Pemerintah Daerah terhadap Kepatuhan Pengungkapan Wajib dalam Laporan Keuangan Pemerintah Daerah (Studi Empiris pada Kabupaten/Kota di Indonesia). Jurnal Akuntansi dan Auditing, 8 (1):1-94.

, M.P. Rusmin dan Brown, A. 2010. Mandatory Disclosure Compliance and Local Government Characteristics: Evidence from Indonesian Municipalities. Penelitian Hibah Publikasi Internasional, LP2M
UNS.

Sukriah, I., Akram dan B.A. Inapty. 2009. Pengaruh Pengalaman Kerja, Independensi, Obyektifitas, Integritas dan Kompetensi terhadap Kualitas Hasil Pemeriksaan. Simposium Nasional Akuntansi XII, Palembang, Indonesia.

Suwardjono. 2014. Teori Akuntansi Perekayasaan Pelaporan Keuangan. Edisi Ketiga. Yogyakarta: BPFE.

Toding, M. dan M.G. Wirakusuma.2013. Faktor-Faktor yang Mempengaruhi Ketepatwaktuan Penyampaian Laporan Keuangan. E-Jurnal Akuntansi Universitas Udayana, 3 (3): 15-31.

Winidyaningrum, C. dan Rahmawati. 2010. Pengaruh Sumber Daya Manusia dan Pemanfaatan Teknologi Informasi terhadap Keterandalan dan Ketepatwaktuan Pelaporan Keuangan Pemerintah Daerah dengan Variabel Intervening Pengendalian Intern Akuntansi (Studi Empiris di Pemda Subosukawonosraten). Simposium Nasional Akuntansi XIII, Purwokerto, Indonesia. 